\title{
Cross-resistance pattern to ACCase-inhibiting herbicides in a rare Trp-2027-Ser mutation Chinese sprangletop (Leptochloa chinensis) population
}

\author{
Guohui Yuan ${ }^{1}$, Zhihui Tian ${ }^{1}$, Tao $\mathrm{Li}^{1}$, Zhenguan Qian ${ }^{1}$, Wenlei Guo ${ }^{2}$, and Guohui Shen ${ }^{1 *}$ \\ ${ }^{1}$ Eco-environmental Protection Research Institute, Shanghai Engineering Research Centre of Low-Carbon Agriculture, Shanghai Academy \\ of Agricultural Sciences, 201403 Shanghai, China. \\ *Corresponding author (ghshen65@163.com). \\ ${ }^{2}$ Institute of Plant Protection, Guangdong Academy of Agricultural Sciences, 510640 Guangzhou, China.
}

Received: 28 June 2020; Accepted: 1 September 2020; doi:10.4067/S0718-58392021000100062

\begin{abstract}
Chinese sprangletop (Leptochloa chinensis [L.] Nees) is an invasive and troublesome grass weed in the aerobic rice fields in China. The extensive and repeated use of acetyl-CoA carboxylase (ACCase)-inhibiting herbicides has resulted in herbicide resistance in this weed. The objectives of this study were to determine the resistance levels to ACCase-inhibiting herbicides of the putative resistant Chinese sprangletop population CM9-1, collected from a paddy field in Shanghai city, in comparison to the susceptible population SJ3-1, and to characterize its molecular resistance mechanism. The wholeplant dose-response experiments suggested that the population CM9-1 had high-level resistance to cyhalofop-butyl, metamifop and fenoxaprop- $P$-ethyl, with resistance index of 27.8,21.4 and 26.2, respectively, and low-level resistance to sethoxydim and pinoxaden, with resistance index of 2.1 and 2.9, respectively, but was sensitive to clethodim. Sequence analysis of the CT domain of ACCase gene revealed a Trp-2027-Ser mutation in resistant plants of the CM9-1 population. This is the first report of the cross-resistance pattern of the Trp-2027-Ser mutation to ACCase-inhibiting herbicides in Chinese sprangletop.
\end{abstract}

Key words: ACCase-inhibiting herbicide, cross-resistance, target-site resistance mutation.

\section{INTRODUCTION}

Chinese sprangletop (Leptochloa chinensis [L.] Nees) is an invasive and troublesome grass weed in the rice growing regions in the world (Benvenuti et al., 2004). It shows high seed production, great adaptability and marked competitiveness (Chauhan and Johnson, 2008). Chin (2001) reported that rice yield was severe losses of up to 55\% when two plants of Chinese sprangletop competed with rice in a pot experiment.

Acetyl-CoA carboxylase (ACCase; EC 6.4.1.2) is a multifunctional, biotinylated protein, which catalyzes the carboxylation of acetyl-CoA to malonyl-CoA in the synthesis of fatty acids (Numa et al., 1965). In plant, two forms of the ACCase enzyme have been identified as cytoplasmic and plastidic. The ACCase-inhibiting herbicides block the fatty acid biosynthesis in the Gramineae by the inhibition of their plastidic ACCase causing plant death. Since their introduction in the late 1970s, the ACCase-inhibiting herbicides constitute one of the important groups of commercial herbicides for controlling a number of grass weed species. So far, there are three chemical families of ACCase-inhibiting herbicides: aryloxyphenoxypropionate (APP), cyclohexanedione (CHD), and phenylpyrazoline (PPZ). Chuah et al. (2006) found that the APP herbicide cyhalofop-butyl in combination with the CHD herbicide sethoxydim provided good control of Chinese sprangletop in rice crops. 
However, the repeated use of the ACCase-inhibiting herbicides in a site can develop resistance in some weeds. To date, 49 grass weed species in locations worldwide have evolved resistance to at least one ACCase-inhibiting herbicide (Heap, 2020). The first fenoxaprop- $P$-ethyl resistant Chinese sprangletop genotype BLC1 was detected in a field with a history of eight applications of fenoxaprop- $P$-ethyl and one application of cyhalofop-butyl in Thailand in 2002 (Maneechote et al., 2005). Pornprom et al. (2006) reported Chinese sprangletop with resistance to fenoxaprop- $P$-ethyl was conferred by a modified ACCase at the target site. In most cases, resistance to ACCase-inhibiting herbicides is attributable to amino acid substitutions (AASs) in the carboxyl transferase (CT) domain of the ACCase gene, resulting in herbicide insensitivity. At least 11 AASs in seven conserved positions of the ACCase gene (Ile-1781, Trp-1999, Trp-2027, Ile-2041, Asp-2078, Cys-2088, and Gly-2096) were described as target-site based resistance (TSR) mechanisms (Liu et al., 2019). In general, the various AASs result from the different cross-resistance patterns to the ACCase-inhibiting herbicides. In addition, non-target-site based (NTSR) mechanisms, such as enhanced metabolism, reduced herbicide absorption and translocation may also confer resistance to the ACCase-inhibiting herbicides in some weed species (Scarabel et al., 2015). Due to their complexity and diversity, these mechanisms are less studied and hence poorly understood (Mei et al., 2017; Anagnostopoulos et al., 2020).

In China, two APP herbicides cyhalofop-butyl and fenoxaprop- $P$-ethyl have been registered to control Chinese sprangletop in rice crops (http://www.icama.org.cn). However, the continuous use of these herbicides in the intensive rice producing areas has become a great concern due to the very poor control of Chinese sprangletop (Zhang, 2003). The present study identified a Chinese sprangletop population that is resistant to ACCase-inhibiting herbicides. The ACCase gene sequencing of the resistant population revealed that a very rare Trp-2027-ser mutation in the CT domain. This is the first report of the cross-resistance pattern of the Trp-2027-Ser mutation to ACCase-inhibiting herbicides in Chinese sprangletop. Understanding the different mechanisms of cross-resistance patterns could be useful for improved management of resistant weeds and delay the expansion or overcome the ACCase-inhibiting herbicide resistance.

\section{MATERIALS AND METHODS}

\section{Seed collection and plant material preparation}

In October 2016, seeds of the putative resistant Chinese sprangletop (Leptochloa chinensis [L.] Nees) population CM91 were collected from a paddy field in Chongming district of Shanghai city (31 ${ }^{\circ} 37^{\prime} 7.2^{\prime \prime} \mathrm{N} ; 121^{\circ} 40^{\prime} 31.4^{\prime \prime}$ E). This field was under a rice-wheat rotation and had approximate one-decade history of acetyl-CoA carboxylase (ACCse)-inhibiting herbicides usage, specifically cyhalofop-butyl for Chinese sprangletop control in rice. A susceptible Chinese sprangletop population SJ3-1 was collected in 2016 from an uncultivated field with no history of herbicide application in Songjiang district of Shanghai city (3056 $\left.8.0^{\prime \prime} \mathrm{N} ; 121^{\circ} 2^{\prime} 54.0^{\prime \prime} \mathrm{E}\right)$, served as the control in this study. The matured seeds of Chinese sprangletop were collected from 20 plants randomly distributed in the field and then were air-dried, cleaned, and stored at room temperature for further use in the following experiments.

The Chinese sprangletop seeds were sown in plastic trays $(60 \times 30 \times 3.5 \mathrm{~cm})$ filled with Pindstrup substrate $(\mathrm{pH} 6.0$, 0-6 mm, Pindstrup Mosebrug A/S, Ryomgaard, Denmark) for germination. Two weeks after germination, the seedlings of each population were transplanted into $10 \times 10 \times 9 \mathrm{~cm}$ plastic pots $\left(10\right.$ plants pot $\left.^{-1}\right)$ containing a 1:3 (w/w) potting mixture of sand and Pindstrup substrate. The plants were grown in a controlled greenhouse (natural light and a temperature regime of $35 / 25^{\circ} \mathrm{C}$ day/night) with normal fertilization and watering throughout the study.

\section{Whole-plant dose-response experiments}

Herbicide treatments were applied at the 3- to 4-leaf seedling stage with a laboratory spray chamber equipped with one 8002 XR VS flat-fan nozzle (TeeJet Technologies, Glendale Heights, Illinois, USA) calibrated to deliver $450 \mathrm{~L} \mathrm{ha}^{-1}$ at a pressure of $270 \mathrm{kPa}$. The herbicide doses applied to the Chinese sprangletop populations CM9-1 and SJ3-1 are listed in Table 1. The herbicides used for whole-plant dose-response experiments were: cyhalofop-butyl (butyl (2R)-2-[4-(4cyano-2-fluorophenoxy)phenoxy]propanoate; $100 \mathrm{~g} \mathrm{~L}^{-1} \mathrm{EC}$, Dow AgroSciences, Beijing, China); metamifop ((2R)-2-[4[(6-chloro-2-benzoxazolyl)oxy]phenoxy]- $N$-(2-fluorophenyl)- $N$-methylpropanamide; $10 \%$ EC, FMC, Suzhou, China); fenoxaprop-P-ethyl (ethyl (R)-2-[4-(6-chlorobenzoxazol-2-yloxy)phenoxy]propionate; $69 \mathrm{~g} \mathrm{~L}^{-1} \mathrm{EW}$, Bayer, Hangzhou, China); sethoxydim ((5RS)-2-[(EZ)-1-(ethoxyimino)butyl]-5-[(2RS)-2-(ethylthio)propyl]-3-hydroxycyclohex-2-en1-one; $12.5 \%$ EC, Sino-Agri Group, Tianjin, China); clethodim ((5RS)-2-\{(1EZ)-1-[(2E)-3-chloroallyloxyimino] 
Table 1. Herbicide treatments applied for the dose-response experiments.

\begin{tabular}{|c|c|c|c|}
\hline $\begin{array}{l}\text { Herbicide } \\
\text { type }\end{array}$ & Herbicide & Population & Dose $^{1}$ \\
\hline & & & g ai ha ${ }^{-1}$ \\
\hline \multirow[t]{6}{*}{ APP } & Cyhalofop-butyl & SJ3-1 & $6.6,13.1,52.5, \mathbf{1 0 5 . 0}, 210.0,420.0$ \\
\hline & & CM9-1 & $52.5, \mathbf{1 0 5 . 0}, 210.0,420.0,1680.0,3360.0$ \\
\hline & Metamifop & $\mathrm{SJ} 3-1$ & $7.5,15.0,60.0, \mathbf{1 2 0 . 0}, 240.0,480.0$ \\
\hline & & CM9-1 & $60.0, \mathbf{1 2 0 . 0}, 240.0,480.0,1920.0,3840.0$ \\
\hline & Fenoxaprop- $P$-ethyl & SJ3-1 & $1.6,3.2,6.5,25.9, \mathbf{5 1 . 8}, 103.5$ \\
\hline & & CM9-1 & $6.5,25.9, \mathbf{5 1 . 8}, 103.5,207.0,828.0$ \\
\hline \multirow[t]{4}{*}{ CHD } & Sethoxydim & SJ3-1 & $11.7,23.4,93.8, \mathbf{1 8 7 . 5}, 375.0,1500.0$ \\
\hline & & CM9-1 & $11.7,23.4,93.8, \mathbf{1 8 7 . 5}, 375.0,1500.0$ \\
\hline & Clethodim & SJ3-1 & $4.5,9.0,36.0, \mathbf{7 2 . 0}, 144.0,576.0$ \\
\hline & & CM9-1 & $4.5,9.0,36.0, \mathbf{7 2 . 0}, 144.0,576.0$ \\
\hline \multirow[t]{2}{*}{ PPZ } & Pinoxaden & SJ3-1 & $37.5, \mathbf{7 5 . 0}, 150.0,300.0,1200.0,2400.0$ \\
\hline & & CM9-1 & $37.5, \mathbf{7 5 . 0}, 150.0,300.0,1200.0,2400.0$ \\
\hline
\end{tabular}

APP: Aryloxyphenoxypropionate; CHD: cyclohexanedione; PPZ: phenylpyrazoline.

${ }^{1}$ The number in bold stand for the recommended field dose of each herbicide.

propyl\}-5-[(2RS)-2-(ethylthio)propyl]-3-hydroxycyclohex-2-en-1-one; $120 \mathrm{~g} \mathrm{~L}^{-1} \mathrm{EC}$, BrightMart CropScience, Foshan, China) and pinoxaden (8-(2,6-diethyl-p-tolyl)-1,2,4,5-tetrahydro-7-oxo-7H-pyrazolo[1,2-d][1,4,5]oxadiazepin-9-yl 2,2-dimethylpropionate; 5\% EC, Syngenta, Suzhou, China). At $21 \mathrm{~d}$ after treatment (DAT), the dry weight of aboveground plant biomass was assessed. The harvested plants were oven-dried for $72 \mathrm{~h}$ at $80^{\circ} \mathrm{C}$, and weighed.

\section{Amplification and sequencing of ACCase gene fragment}

Fresh leaf tissues from 50 survivor plants of CM9-1 population were collected at 21 DAT of cyhalofopbutyl (105 $\mathrm{g}_{\text {ai }} \mathrm{ha}^{-1}$ ). For the susceptible population SJ3-1, leaf tissues were collected from 10 non-treated plants. HiDNAsecure Plant Kit (Tiangen Biotech, Beijing, China) was used to extract genomic DNA from $100 \mathrm{mg}$ leaf tissue under liquid nitrogen as the manufacturer's instructions. The primer pair QJ-F/-R (QJ-F: 5'-ATTCCTATGGAGCGTCCTG-3' and QJ-R: 5'-TCCTTCGCAAGAACATCC-3') was designed based on the published sequences of the ACCase gene of Alopecurus myosuroides (GenBank nr AJ310767) and Lolium multiflorum (AY710293) using the Primer Analysis Software (Oligo version 6.67, Molecular Biology Insights, Colorado Springs, Colorado, USA). This primer sequence covered all seven known mutation sites conferring resistance to the ACCase-inhibiting herbicide. The polymerase chain reaction (PCR) amplification was performed using the Premix Taq kit (Ex Taq Version 2.0; Takara Bio, Beijing, China), which contained $25 \mu \mathrm{L}$ Premix Taq, $2 \mu \mathrm{L}$ each primer $(10 \mu \mathrm{M}), 2 \mu \mathrm{L}$ genomic DNA and $\mathrm{ddH}_{2} \mathrm{O}$ in $50 \mu \mathrm{L}$ mixture. The thermal cycling program consisted of an initial denaturing step at $94{ }^{\circ} \mathrm{C}$ for $3 \mathrm{~min}$, followed by 35 cycles of $60 \mathrm{~s}$ denaturation at $94{ }^{\circ} \mathrm{C}, 30 \mathrm{~s}$ annealing at $52{ }^{\circ} \mathrm{C}, 90 \mathrm{~s}$ elongation at $72{ }^{\circ} \mathrm{C}$, and a final extension of $10 \mathrm{~min}$ at $72{ }^{\circ} \mathrm{C}$. PCR product was electrophoresed on $1.0 \%$ agarose gel and visualized under UV light. The desired PCR band was purified with the EasyPure Quick Gel Extraction Kit (TransGen Biotech, Beijing, China), and then was cloned into the pEASY-T1 Cloning vector (TransGen Biotech) and transformed into Escherichia coli (Trans1-T1 Phage Resistant Chemically Competent Cell). Positive clones were commercially sequenced in the forward and reverse directions (Sangon Biotech, Shanghai, China). At least 10 clones for each biological replicate were sent for sequencing. The sequencing data were analyzed using the software DNAMAN (version 6.0.3, Lynnon Biosoft, Quebec, Canada).

\section{Statistical analysis}

The experiments were repeated twice, arranged in a completely randomized design with three replicates per treatment. The data obtained from two runs were expressed as percentage of untreated controls and then were pooled, as the test for homogeneity of variance showed that the variance across runs was coincident. Mean growth reduction rates $\left(\mathrm{GR}_{50}\right)$, herbicide rate causing $50 \%$ plant shoot biomass reduction, were obtained by the nonlinear regression procedure in GraphPad Prism (version 5.01, GraphPad software, San Diego, California, USA) (Ritz et al., 2017):

$$
y=c+\left\{(\mathrm{d}-\mathrm{c}) /\left[1+\left(x / \mathrm{GR}_{50}\right)^{\wedge} b\right]\right\}
$$


where $\mathrm{c}$ is the lower limit, $\mathrm{d}$ is the upper limit, $\mathrm{b}$ is the slope around the $\mathrm{GR}_{50}$, and $\mathrm{y}$ is the growth response (percentage of the control) at the herbicide dose (x).

The resistance index (RI) was calculated as the $\mathrm{GR}_{50}$ value of the resistant population (R) divided by the $\mathrm{GR}_{50}$ value of the susceptible population $(\mathrm{S})$.

\section{RESULTS}

\section{Cross-resistance to ACCase-inhibiting herbicides}

For the aryloxyphenoxypropionate (APP) herbicides treatment, all plants from the CM9-1 population survived the recommended field rates of any APP herbicides, with only slight $(<9 \%)$ growth reduction (Figure 1). In contrast, no plants from the SJ3-1 population survived the recommended field rates. Based on the $\mathrm{GR}_{50}$ values, CM9-1 population was 27.8-, 21.4- and 26.2-fold resistant to cyhalofop-butyl, metamifop and fenoxaprop- $P$-ethyl compared with the SJ3-1 population, respectively (Table 2 ).

Figure 1. Dose-response curves of the putative resistant (CM9-1) and susceptible (SJ3-1) Leptochloa chinensis populations to six acetyl-CoA carboxylase (ACCase) inhibitors.
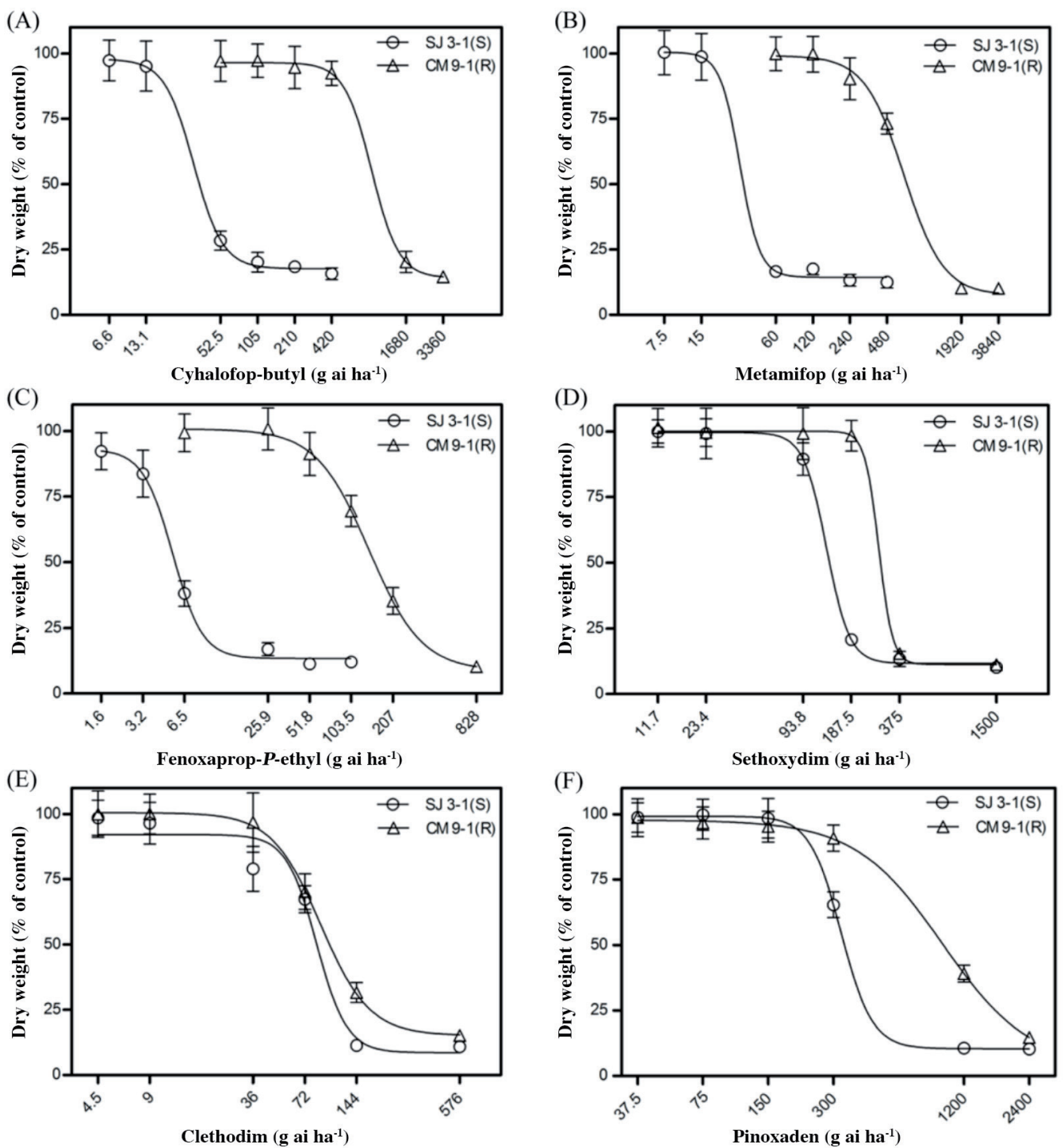

Vertical bars represent standard errors of the means. 
For the cyclohexanedione (CHD) herbicides treatment, sethoxydim reduced the dry weight of the control to $1.6 \%$ and 79.3\% for the CM9-1 and SJ3-1 populations at the recommended field rate, respectively, and clethodim reduced the dry weight of the control to $29.7 \%$ and $32.7 \%$ for the CM9-1 and SJ3-1 populations at the recommended field rate, respectively (Figure 1). As shown in Table 2, the RI of the CM9-1 population to sethoxydim and clethodim were 2.1 and 1.1 , respectively.

For the phenylpyrazoline (PPZ) herbicide pinoxaden treatment, plants from any Chinese sprangletop populations exhibited only about $3 \%$ growth reduction at the recommended field rate (Figure 1). The GR 50 value for the CM9-1 population was $955.9 \mathrm{~g}$ ai ha-1 ${ }^{-1}$, which was 2.9 -fold greater than the SJ3-1 population (Table 2).

\section{ACCase gene fragment sequencing}

A 1753-bp ACCase gene fragment was amplified and sequenced for both the CM9-1 and SJ3-1 populations. The gene sequences of the ACCase-amplified fragment displayed more than $98 \%$ homology with the documented plastidic ACCase gene sequence of A. myosuroides (AJ310767) and L. multiflorum (AY710293). By comparing the ACCase amino acid sequences of the amplified fragment, which derived from 50 individual plants of the CM9-1 population, with the sequences of the SJ3-1 population, all tested individual plants of the CM9-1 population showed a substitution of Trp (TGG) to Ser (TCG) at position 2027 (Table 3). Meanwhile, no published mutation was detected in the plants from the CM9-1 population.

Table 2. Estimated herbicide dose required for $50 \%$ reduction of the percentage of shoot biomass relative to untreated controls $\left(G_{50}\right.$, with $95 \%$ confidence interval in brackets) and resistance index (RI) calculated on the basis of the susceptible population.

\begin{tabular}{|c|c|c|c|}
\hline \multirow[b]{2}{*}{ Herbicide } & \multicolumn{3}{|c|}{$\mathrm{GR}_{50}$} \\
\hline & CM9-1 (R) & SJ3-1 (S) & RI \\
\hline & $\longrightarrow$ & & \\
\hline Cyhalofop-butyl & $883.8(661.7,1180.0)$ & $31.8(20.2,50.2)$ & 27.8 \\
\hline Metamifop & $658.2(393.8,1100.0)$ & $30.7(10.7,88.3)$ & 21.4 \\
\hline Fenoxaprop- $P$-ethyl & $138.7(116.6,164.9)$ & $5.3(4.2,6.8)$ & 26.2 \\
\hline Sethoxydim & $277.8(229.9,335.7)$ & $131.2(117.4,146.6)$ & 2.1 \\
\hline Clethodim & $88.8(79.9,98.8)$ & $84.2(40.1,176.9)$ & 1.1 \\
\hline Pinoxaden & $955.9(800.3,1142.0)$ & $325.2(303.6,348.2)$ & 2.9 \\
\hline
\end{tabular}

R: Resistant; S: susceptible.

Table 3. Sequence alignment and derived amino acid of the resistant and susceptible Leptochloa chinensis populations.

\begin{tabular}{lccccccc}
\hline & \multicolumn{5}{c}{ Amino acid position, relative sequence of nucleotide and deduced amino acid } \\
\cline { 2 - 7 } Population & 1781 & 1999 & 2027 & 2041 & 2078 & 2088 & 2096 \\
\hline SJ3-1 (S) & ATA & TGG & TGG & ATT & GAT & TGC & GGC \\
& Ile & Trp & Trp & Ile & Asp & Cys & Gly \\
CM9-1 (R) & ATA & TGG & $\underline{\text { TCG }}$ & ATT & GAT & TGC & GCC \\
& Ile & Trp & $\underline{\text { Ser }}$ & Ile & Asp & Cys & Gly \\
\hline
\end{tabular}

S: Susceptible; R: resistant.

${ }^{1}$ Amino acid residue sequence according to the plastidic acetyl-CoA carboxylase (ACCase) sequence of Alopecurus myosuroides (AJ310767); the mutated amino acid residues and corresponding codon were underlined.

\section{DISCUSSION}

In paddy rice systems, cyhalofop-butyl has been the predominant herbicide used to control Chinese sprangletop since 2006, which was first registered to selectively control grass weeds in China (Yuan et al., 2019). Devine (1997) reported that ACCase inhibitor resistant biotypes may evolve after 6 to $10 \mathrm{yr}$ of selection pressure, especially in crop systems in which the continued use of these herbicides as the only grass weed control measure. The over-reliance application of cyhalofop-butyl in rice fields has led to resistance in some weeds, for example, Diplachne fusca (Yuan et al., 2019), Leptochloa chinensis (Peng et al., 2020) and Eleusine indica (Deng et al., 2020). Yu et al. (2017) reported that repeated use 
of cyhalofop-butyl over the past $5 \mathrm{yr}$ has led to the development of resistant Chinese sprangletop. In this study, the CM9-1 population was exposed to cyhalofop-butyl for about $10 \mathrm{yr}$, which could explain the ACCase inhibitor resistance observed.

According to the $\mathrm{R} / \mathrm{S}$ ratio of $\mathrm{GR}_{50}$, the herbicide resistance levels have been classified as high ( $\left.>12\right)$, moderate $(6$ to 12 ), low (2 to 6), and sensitive $(<2)$ (Ahmad-Hamdani et al., 2017). The whole-plant dose-response experiments suggested that the population CM9-1 had high-level resistance to cyhalofop-butyl, metamifop and fenoxaprop- $P$-ethyl, and low-level resistance to sethoxydim and pinoxaden, but was sensitive to clethodim. The similar cross-resistance pattern was also observed for the resistant Pseudosclerochloa kengiana population JS-25, which harboring the Trp-2027-Cys mutation showed high levels of resistance to the APP herbicides and low level of resistance to sethoxydim and pinoxaden (Yuan et al., 2017). Beckie and Tardif (2012) reported that an examination of cross-resistance patterns in herbicideresistant weed populations could help inform proactive or reactive weed management by determining less resistanceprone alternative herbicide options for growers. In our study, the resistant population CM9-1 was still susceptible to clethodim. Clethodim was typically used to control grass weeds infesting dicotyledonous crops such as oilseed rape and soybean, and was considered the lowest resistance risk ACCase-inhibiting herbicide (Yuan et al., 2017). Therefore, crop rotation with soybean (and thus clethodim) may be used as a part of a management system for the herbicide-resistant Chinese sprangletop studied here.

In most cases, cross-resistance to herbicides that act under the same mode of action is caused by target-site based resistance (TSR) mechanisms (Beckie and Tardif, 2012). To date, four AASs of ACCase (Ile-1781-Leu, Trp-1999-Cys, Trp-2027-Cys, and Trp-2027-Ser) have been published in Chinese sprangletop (Yu et al., 2017; Deng et al., 2019; Peng et al., 2020). The cross-resistance patterns of Ile-1781-Leu and Trp-2027-Cys mutations showed resistance to fenoxaprop$P$-ethyl, metamifop, clethodim and pinoxaden, and the Trp-1999-Cys mutation was resistant to fenoxaprop- $P$-ethyl, metamifop and pinoxaden in Chinese sprangletop (Deng et al., 2019). This study indicated that a single nucleotide mutation (TGG to TCG) occurred in Trp substitution by Ser at position 2027 in ACCase gene of the CM9-1 population. And all tested individual plants of the CM9-1 populations carried the Trp-2027-Ser mutation. Therefore, the Trp-2027Ser mutation was very likely one of the key reasons resulting in the ACCase inhibitor resistance in the resistant Chinese sprangletop population. To our knowledge, this is the first report of the cross-resistance pattern of the Trp-2027-Ser mutation to ACCase-inhibiting herbicides in Chinese sprangletop. From the homology model of Digitaria insularis ACCase, it was indicated that the Trp2027 residue is located near the CT active-site cavity (Takano et al., 2020). The ACCase enzyme assays and three-dimensional model analyses showed that the Trp2027 residue is involved in sensitivity to ACCase inhibitors (Délye et al., 2005). Previous study reported that the Trp-2027-Cys mutation probably influences the lipophilic properties of the ACCase binding site, thus confers resistance to the ACCase-inhibiting herbicides (Délye et al., 2005). In the present study, the Trp-2027-Ser mutation involves the substitution of hydrophobic aromatic amino acid (Trp) to a small and polar amino acid (Ser), which may also hamper the access of herbicide to the ACCase binding site by inducing a number of small allosteric changes. In addition, non-target-site based (NTSR) mechanisms are often present in the ACCase inhibitor resistant populations that already carry one of the AASs, such as in Polypogon fugax (Zhao et al., 2019a), Lolium rigidum (Han et al., 2016) and Alopecurus aequalis (Guo et al., 2016; Zhao et al., 2019b). Thus, further research into NTSR metabolisms in Chinese sprangletop is needed.

\section{CONCLUSIONS}

This study reports that the CM9-1 population carrying the Trp-2027-Ser mutation exhibited broad cross-resistance to the aryloxyphenoxypropionate (APP) herbicides cyhalofop-butyl, metamifop and fenoxaprop- $P$-ethyl, the cyclohexanedione (CHD) herbicide sethoxydim, and the phenylpyrazoline (PPZ) herbicide pinoxaden, but was sensitive to the CHD herbicide clethodim.

\section{ACKNOWLEDGEMENTS}

This research was financially supported by the Agriculture Research System of Shanghai (201903), the Science and Technology Commission of Shanghai Municipality (16391901800) and Shanghai Academy of Agricultural Sciences for the Program of Excellent Research Team [2018 (B-01)]. The authors thank all the workers for assistance in conducting this research. 


\section{REFERENCES}

Ahmad-Hamdani, M.S., Owen, M.J., Yu, Q., and Powles, S.B. 2017. ACCase-inhibiting herbicide-resistant Avena spp. populations from the western Australian grain belt. Weed Technology 26:130-136.

Anagnostopoulos, C., Stasinopoulou, P., Kanatas, P., and Travlos, I. 2020. Differences in metabolism of three Conyza species to herbicides glyphosate and triclopyr revealed by LC-MS/MS. Chilean Journal of Agricultural Research 80:100-107.

Beckie, H.J., and Tardif, F.J. 2012. Herbicide cross resistance in weeds. Crop Protection 35:15-28.

Benvenuti, S., Dinelli, G., and Bonetti, A. 2004. Germination ecology of Leptochloa chinensis: a new weed in the Italian rice agro-environment. Weed Research 44:87-96.

Chauhan, B.S., and Johnson, D.E. 2008. Germination ecology of Chinese sprangletop (Leptochloa chinensis) in the Philippines. Weed Science 56:820-825.

Chin, V. 2001. Biology and management of barnyardgrass, red sprangletop and weedy rice. Weed Biology and Management 1:37-41.

Chuah, T.-S., Maziah, B.M., Nuraziah, B.M.Y., and Cha, T.-S. 2006. Reduced rates of tank mixtures for red sprangletop (Leptochloa chinensis [L.] Nees) and greater club-rush (Scirpus grossus [L.] f.) control in rice. Weed Biology and Management 6:245-249.

Délye, C., Zhang, X.Q., Michel, S., Matejicek, A., and Powles, S.B. 2005. Molecular bases for sensitivity to acetyl-coenzyme A carboxylase inhibitors in black-grass. Plant Physiology 137:794-806.

Deng, W., Cai, J., Zhang, J., Chen, Y., Chen, Y., Di, Y., et al. 2019. Molecular basis of resistance to ACCase-inhibiting herbicide cyhalofop-butyl in Chinese sprangletop (Leptochloa chinensis (L.) Nees) from China. Pesticide Biochemistry and Physiology 158:143-148.

Deng, W., Yang, Q., Chen, Y., Yang, M., Xia, Z., Zhu, J., et al. 2020. Cyhalofop-butyl and glyphosate multiple herbicide resistance evolved in an Eleusine indica population collected in Chinese direct-seeding rice. Journal of Agricultural and Food Chemistry 68:2623-2630.

Devine, M.D. 1997. Mechanisms of resistance to acetyl-coenzyme A carboxylase inhibitors: a review. Pesticide Science 51:259-264.

Guo, W., Lv, L., Zhang, L., Li, Q., Wu, C., Lu, X., et al. 2016. Herbicides cross resistance of a multiple resistant short-awn foxtail (Alopecurus aequalis Sobol.) population in wheat field. Chilean Journal of Agricultural Research 76:163-169.

Han, H., Yu, Q., Owen, M.J., Cawthray, G.R., and Powles, S.B. 2016. Widespread occurrence of both metabolic and target-site herbicide resistance mechanisms in Lolium rigidum populations. Pest Management Science 72:255-263.

Heap, I. 2020. The international survey of herbicide resistant weeds. Online. Available at www.weedscience.org (accessed April 2020).

Liu, B., Ding, F., Wang, M., Wang, F., Luo, X., and Li, L. 2019. Cross-resistance pattern to ACCase-inhibiting herbicides in a novel Trp1999Leu mutation American sloughgrass (Beckmannia syzigachne) population. Pesticide Biochemistry and Physiology 159:80-84.

Maneechote, C., Samanwong, S., Zhang, X.-Q., and Powles, S.B. 2005. Resistance to ACCase-inhibiting herbicides in sprangletop (Leptochloa chinensis). Weed Science 53:290-295.

Mei, Y., Si, C., Liu, M., Qiu, L., and Zheng, M. 2017. Investigation of resistance levels and mechanisms to nicosulfuron conferred by non-target-site mechanisms in large crabgrass (Digitaria sanguinalis L.) from China. Pesticide Biochemistry and Physiology 141:84-89.

Numa, S., Bortz, W.M., and Lynen, F. 1965. Regulation of fatty acid synthesis at the acetyl-CoA carboxylation step. Advances in Enzyme Regulation 3:407-423.

Peng, Y., Pan, L., Liu, D., Cheng, X., Ma, G., Li, S., et al. 2020. Confirmation and characterization of cyhalofop-butyl-resistant Chinese sprangletop (Leptochloa chinensis) populations from China. Weed Science 68:253-259.

Pornprom, T., Mahatamnuchoke, P., and Usui, K. 2006. The role of altered acetyl-CoA carboxylase in conferring resistance to fenoxaprop- $P$-ethyl in Chinese sprangletop (Leptochloa chinensis (L.) Nees). Pest Management Science 62:1109-1115.

Ritz, C., Kniss, A.R., and Streibig, J.C. 2017. Research methods in weed science: Statistics. Weed Science 63:166-187.

Scarabel, L., Pernin, F., and Délye, C. 2015. Occurrence, genetic control and evolution of non-target-site based resistance to herbicides inhibiting acetolactate synthase (ALS) in the dicot weed Papaver rhoeas. Plant Science 238:158-169.

Takano, H.K., Melo, M.S.C., Ovejero, R.F.L., Westra, P.H., Gaines, T.A., and Dayan, F.E. 2020. Trp2027Cys mutation evolves in Digitaria insularis with cross-resistance to ACCase inhibitors. Pesticide Biochemistry and Physiology 164:1-6.

Yu, J., Gao, H., Pan, L., Yao, Z., and Dong, L. 2017. Mechanism of resistance to cyhalofop-butyl in Chinese sprangletop (Leptochloa chinensis (L.) Nees). Pesticide Biochemistry and Physiology 143:306-311.

Yuan, S., Di, Y., Chen, Y., Chen, Y., Cai, J., and Deng, W. 2019. Target-site resistance to cyhalofop-butyl in bearded sprangletop (Diplachne fusca) from China. Weed Science 67:534-538.

Yuan, G., Guo, W., Du, L., Liu, W., Li, Q., Li, L., et al. 2017. Alleles contributing to acetyl coenzyme A carboxylase (ACCase) resistance in keng stiffgrass (Pseudosclerochloa kengiana) populations from China. Journal of Integrative Agriculture 16:125-134. 
Zhang, Z.E.P.U. 2003. Development of chemical weed control and integrated weed management in China. Weed Biology and Management 3:197-203.

Zhao, N., Ge, L., Yan, Y., Bai, S., Wang, D., Liu, W., et al. 2019a. Trp-1999-Ser mutation of acetyl-CoA carboxylase and cytochrome P450s-involved metabolism confer resistance to fenoxaprop-P-ethyl in Polypogon fugax. Pest Management Science 75:3175-3183.

Zhao, N., Yan, Y., Ge, L., Zhu, B., Liu, W., and Wang, J. 2019b. Target site mutations and cytochrome P450s confer resistance to fenoxaprop- $P$-ethyl and mesosulfuron-methyl in Alopecurus aequalis. Pest Management Science 75:204-214. 